\title{
The Impact of Venture Capital on Innovation
}

\author{
Roberta Dessí*and Nina Yin ${ }^{\dagger}$ \\ Toulouse School of Economics (GREMAQ and IDEI).
}

July 3,2010

\section{INTRODUCTION}

Does venture capital foster productive innovation, and if so, how? Is the impact of venture capital on innovation very large? These questions are not only of theoretical interest: answering them correctly is crucial for designing the best public policies on innovation. Although it accounts for a rather low proportion of total entrepreneurial financing, notably compared to bank finance ${ }^{1}$, venture capital is widely regarded as a key factor in the successful performance of the U.S. in terms of innovation, providing a model that has inspired emulation efforts in many other countries. From this perspective too, it is important to understand the model well, and how it works.

This chapter begins by reviewing the empirical evidence on the impact of venture capital on innovation. We identify some of the key challenges to empirical research in this area, and discuss the methods that have been used to address them. Our review is by no means exhaustive, but several findings emerge clearly.

*IDEI, Toulouse School of Economics, Manufacture des Tabacs, Aile Jean-Jacques Laffont, 21 Allée de Brienne, 31000 Toulouse, France (dessi@cict.fr).

${ }^{\dagger}$ Toulouse School of Economics. 21 Allee de Brienne, 31000 Toulouse, France (yinnina.ccer@gmail.com).

${ }^{1}$ For example, Berger and Udell (1998) find that in the US, 3.59\% of small business finance comes from angel investors, $1.85 \%$ from venture capitalists, and $18.75 \%$ from commercial banks. More recently, using UK data, Cosh, Cumming and Hughes (2009) find that 775 out of 952 firms seeking external finance in their sample approached banks, while only 87 approached venture capital funds and 83 approached private individuals. Moreover, rejection rates were much higher among venture capital funds (46\%) than among banks (17\%). 
First, there is evidence of a substantial impact of venture capital on innovation, measured by patent counts, at the industry level (at least for the U.S.). Although estimates vary, on average a dollar of venture capital appears to be three to four times more potent in stimulating innovation than a dollar of traditional corporate R\&D (Lerner (2002)). Second, there is no corresponding evidence of a significant impact of venture capital on innovation at the individual firm level. We discuss possible explanations for this difference, including the difficulties of adequately controlling for the endogeneity of venture capital investment at the firm level. While valid instruments have been found to address the endogeneity problem at the industry level, this is much harder to achieve at the level of individual firms. Third, there is very little evidence on how venture capital affects innovation.

Concerning the second finding, the theoretical literature on venture capital has focused primarily on one source of endogeneity: the ex-ante screening hypothesis. The idea is that venture capitalists have a comparative advantage in evaluating the entrepreneurs who seek funding from them, and selecting the "best" ones. As discussed in section 2 below, this can bias upwards the estimates of the impact of venture capital on innovation, since firms with better entrepreneurs (projects) are more likely to obtain venture funding and more likely to produce valuable innovations. We argue however that there may be other sources of endogeneity, introducing other biases, possibly going in the opposite direction, and making it difficult to draw inferences from reduced-form estimates obtained with firm-level data.

Concerning the third finding listed above, the theoretical literature has highlighted two main mechanisms whereby venture capitalists affect the performance of their portfolio firms: monitoring and intervention ${ }^{2}$, on the one hand, which alleviates potential moral hazard problems on the side of the entrepreneur, and the provision of advice and support ${ }^{3}$ on the other hand, which helps performance directly. Both mechanisms could, in principle, apply to innovation. However, while there is growing evidence of the role played by venture capitalists in helping to commercialize innovations ${ }^{4}$, as well as their role in helping to recruit key personnel and replace founders with new $\mathrm{CEOs}^{5}$, there is very little direct evidence

\footnotetext{
${ }^{2}$ See, for example, Dessí (2005) and Holmström and Tirole (1997).

${ }^{3}$ See, among others, Bottazzi et al. (2005), Casamatta (2003), Cestone (2000), Cumming, Fleming and Suchard (2005), Dessí (2010), Hellmann (1998), Jeng and Wells (2000), Kaplan et al. (2003), Lerner and Schoar (2005), Repullo and Suarez (2000, 2004), Riyanto and Schwienbacher (2006), and Schmidt (2003).

${ }^{4}$ Colombo, Grilli and Piva (2006), Gans, Hsu and Stern (2002), Hsu (2006).

${ }^{5}$ Hellmann and Puri (2002).
} 
showing that they play an important role in fostering innovation.

There is, nevertheless, evidence from recent work, discussed in section 2 , showing that venture capitalists are highly effective in evaluating the quality of innovations early on, identifying correctly the patent applications that are likely to succeed and lead to the development of valuable new products. Dessí and Yin (2010) build on this observation to develop a theoretical model that highlights some additional ways, beyond monitoring and advising, in which venture capital may influence innovation. In sections 3,4 and 5 we present and analyze a highly simplified model based on Dessí and Yin (2010), to show some of the effects at work and the implications for innovation. The model also illustrates a potential source of endogeneity of venture funding that is unrelated to screening. The theoretical analysis therefore suggests that endogeneity can indeed be an important concern in empirical work. On the positive side, the analysis yields a number of potentially testable predictions: investigating predictions of this kind empirically could help to shed new light on the mechanisms whereby venture capital affects innovation.

The remainder of the chapter is organized as follows. Section 2 presents a brief overview of the empirical evidence on the link between venture capital and innovation. Section 3 introduces a simple theoretical model, based on Dessí (2009) and Dessí and Yin (2010). The model is analyzed in sections 4 and 5. The implications of the model are discussed in section 6 . Section 7 suggests potential avenues for future research and concludes.

\section{VENTURE CAPITAL AND INNOVATION: A BRIEF OVERVIEW OF THE EMPIRICAL EVIDENCE}

A large and growing empirical literature examines, in different ways, the link between venture capital and innovation. Our brief overview, summarised in Table 1 , is not intended to be exhaustive; it only aims to highlight some of the main contributions and implications. Moreover, it focuses on research that explicitly investigated the impact of venture capital on innovation, rather than more generally the impact of venture capitalists on the firms they finance.

A key challenge in this line of research has been to establish a causal relationship between venture capital funding and different measures of innovative performance, such as patent counts. This issue has been addressed with different methodologies, using data at the industry level and the individual firm level. 


\subsection{INDUSTRY DATA}

The difficulty of establishing causality can be illustrated by reference to the following framework. Consider innovative performance at the industry level, denoted by $P_{i t}^{I}$, where the subscript $i$ denotes the industry and $t$ denotes time. Suppose that this depends on total $\mathrm{R} \& \mathrm{D}$ expenditure in the industry $\left(R_{i t}\right)$, on the ratio of venture capital investment to total R\&D expenditure $\left(V_{i t} / R_{i t}\right)$, and on unobserved technological opportunities $\left(w_{i t}\right)$. This suggests estimating the following regression ${ }^{6}$,

$$
\ln P_{i t}^{I}=a+b \ln R_{i t}+c \ln \left(\frac{V_{i t}}{R_{i t}}\right)+u_{i t}
$$

to see whether venture capital has a significant impact on innovation; i.e. whether the estimated coefficient $c$ is statistically significant. The difficulty here is that the unobserved technological opportunities, captured by the error term $u_{i t}$, are likely to be correlated with the explanatory variables: if there is a positive technology shock that increases technological opportunities in a given industry, venture capital investment in that industry is likely to increase, as is total R\&D expenditure. Moreover, there is no reason to believe that they will increase so as to leave the ratio unaffected. To the extent that the explanatory variables are correlated with the error term, OLS estimates of their coefficients will be biased.

The problem can be addressed by estimating an instrumental variable regression, provided appropriate instruments are found. The first paper to do this was Kortum and Lerner (2000). They cleverly exploit the policy shift that occurred in the U.S. in the late 1970s, when the U.S. Department of Labor clarified the Employee Retirement Income Security Act, freeing pensions to invest in venture capital. This led to a sharp increase in the total funds invested in venture capital, unrelated to changes in technological opportunities. Thus it could be used as an instrument in the estimations.

Kortum and Lerner found that, even after instrumenting, venture capital has a substantial positive impact on innovation, as measured by the patent count at the industry level. Their results applied to the period 1965-1992. More recently, Ueda and Hirukawa (2008) have replicated these findings with a longer sample period, up to 2001 (i.e. including the period of very high growth of the U.S. venture capital industry in the late 1990s). They show that venture capital continued to have a substantial positive impact on industry patent counts during the boom

\footnotetext{
${ }^{6}$ See Kortum and Lerner (2000) for the theoretical underpinnings of this specification.
} 
period of the late 1990s.

Ueda and Hirukawa then go on to study the impact of venture capital on different measures of innovative performance, including total factor productivity (TFP) growth. They find that, in contrast to the results with patent counts, venture capital does not significantly and positively affect TFP growth. It seems therefore that venture capital funding may be particularly important for one measure of innovative performance: patenting success.

\subsection{INDIVIDUAL FIRM DATA}

The findings just discussed at the industry level clearly show the need to understand how venture capital funding may affect innovation. This is also crucial in thinking about implications for public policy.

However, the empirical evidence on the mechanisms whereby venture funding impacts on innovation is limited. Hellmann and Puri (2000) examine a sample of high-technology companies in Silicon Valley, both venture-funded and nonventure-funded. They classify companies as "innovators" or "imitators" based on information about their initial strategy. Innovators are either creating a new market, or introducing a radical innovation in an existing market, or developing a technology that will lead to either of the first two outcomes.

Hellmann and Puri report several interesting results. They find that innovators are more likely to be financed by venture capitalists than imitators. This result could be consistent with different possibilities though: it may be that venture capitalists have a comparative advantage in fostering innovation, through the provision of valuable advice for example. It may also be that venture capitalists have a comparative advantage in identifying the most promising innovative companies.

Hellmann and Puri also find evidence that venture-backed companies, especially innovators, are faster in bringing their product to market. Again, this could be due to helpful advice by venture capitalists, or to selection of companies with characteristics that are observed by the venture capitalists but not measured in the available data, which make them more likely to bring their product to market in a shorter time.

Some of the more recent studies of the relationship between venture funding and innovation suggest that venture capitalists' ability to evaluate the quality of innovations (patent applications) plays an important role, and that venture capitalists may help to foster growth - but not innovation. Engel and Keilbach (2007) 
analyze a panel of young German firms. They find that firms with a higher number of patent applications are more likely to receive venture funding. Once the firms are venture-funded, they tend to grow more than comparable non-venture firms, while their innovative performance (in terms of patent applications) does not differ significantly. Caselli, Gatti and Perrini (2006) and Peneder (2007) find a similar result using data on Italian and Austrian firms, respectively. These studies carefully estimate propensity scores to match venture-funded firms with otherwise comparable non-venture firms, and thereby minimize the potential selection bias ${ }^{7}$. Nevertheless, the problem remains to the extent that venture-backed firms differ from the non-venture firms they are matched with in terms of unobservable characteristics (observed by the venture capitalists that finance them).

Haeussler, Harhoff and Müller (2009) examine data on German and British biotechnology firms. Their results are consistent with those of the studies just cited: firms with a higher number of patent applications obtain venture funding sooner. The authors go on to investigate the quality of patents, measured by received citations, and find that firms with higher patent quality receive venture funding more quickly. Importantly, the citations occur mostly after the venture capital investment decision, implying that venture capitalists are highly effective in identifying high-quality innovations (patent applications). This finding will play an important role in the theoretical analysis we develop below.

\subsection{IS THERE A LINK?}

Comparing the evidence from studies using firm-level and industry-level data raises a question: why does venture funding appear to have a positive impact on innovation at the industry level but not at the firm level? The comparison is obviously fraught with difficulties, since different studies use different sample sizes and data from different countries and time periods. This is potentially important given that the venture capital industry has developed quite differently in different countries.

There is also a more fundamental difficulty though, as suggested in the discussion above: it is very hard to address the selection issue in a completely satisfactory way with firm-level data. This would require an experiment in which

\footnotetext{
${ }^{7}$ The propensity score methodology is also employed by Da Rin and Penas (2007). Their paper attempts to address directly the question of how venture capital affects innovation by focusing on the determinants of absorptive capacity. They report that indeed venture capital favors the build-up of absorptive capacity.
} 
start-up firms are randomly assigned to receive venture funding or funding from other sources; alternatively, it would require the availability of appropriate instruments, highly correlated with venture capital investment in the firm but uncorrelated with unobservable (to the econometrician) firm characteristics which affect innovative performance.

In the absence of such solutions, could we nevertheless argue that firm-level studies may provide persuasive evidence against the hypothesis of a positive impact of venture capital on innovation? Theoretical analysis can shed light on this claim.

In the existing theoretical literature on venture capital, the main hypothesis concerning selection has been the ex-ante screening hypothesis: venture capitalists, according to this hypothesis, are highly effective in evaluating the entrepreneurs that seek funding from them, and selecting the "better" ones ${ }^{8}$. Applied to innovation, this hypothesis suggests that venture capitalists will select and fund the entrepreneurs with the greatest potential for innovative success. Since the entrepreneur's potential is not observed by the econometrician, empirical estimates of the impact of venture funding on innovative performance will tend to be biased upward; intuitively, some of the estimated effect will be due to the entrepreneur's potential, which makes it more likely that he will be venture-funded and that he will be successful in innovating.

If we could be sure that estimates will be biased upward, we might be able to make some inferences concerning the true underlying relationships. However, more recent theoretical work suggests that, at least in some circumstances, other influences may generate a downward bias. We illustrate this possibility below. If different and opposing biases are present at the same time, the net effect is not clear. It then becomes difficult to draw inferences from reduced-form estimates obtained with firm-level data. An alternative but complementary approach might be to exploit the full power of theoretical analysis and test a richer set of predictions, as suggested at the end of this chapter.

We can summarize the main findings from our brief overview of the empirical literature as follows. First, there is evidence of a substantial impact of venture capital on innovation, measured by patent counts, at the industry level (at least for the U.S.). Second, there is no corresponding evidence of a significant impact of venture capital on innovation at the individual firm level. One possible reason

\footnotetext{
${ }^{8}$ See, for example, Brander et al. (2002), Casamatta and Haritchabalet (2006, 2007), Garmaise (2006) and Ueda (2004). Kaplan and Stromberg (2004) and Lerner (1994) provide evidence of venture capitalists' ex ante screening role.
} 
for this difference is the difficulty of adequately controlling for the endogeneity of venture capital investment at the firm level. While valid instruments have been found to address the endogeneity problem at the industry level, this is much harder to achieve at the level of individual firms. Third, there is very little evidence on how venture capital affects innovation. Here theoretical analysis can shed some light, and suggest promising avenues for future empirical work. In what follows, we focus on this possibility.

\section{A SIMPLE MODEL}

This section introduces a very simple model, based on Dessí (2009) and Dessí and Yin (2010). The main purpose of the model is to illustrate some of the ways in which venture capital may affect innovation.

There are two periods and three dates, $t=0,1,2$. At the beginning of the first period $(t=0)$, an entrepreneur with an innovative idea seeks funding to invest in turning the idea into a valuable new product or process. At the end of the first period $(t=1)$, the outcome of this investment is realized. If the investment is successful in producing a valuable innovation, the entrepreneur can apply for a patent. At this stage, another entrepreneur may enter the industry and invest in a competing project. During the second period, the patent application succeeds with probability $\beta$. The returns from all projects are realized at the end of the second period $(t=2)$. Entrepreneurs possess no capital and need to raise finance from outside investors. For simplicity, there is no discounting. All agents in the model are assumed to be risk neutral and protected by limited liability.

\subsection{THE INCUMBENT}

The first entrepreneur, henceforth also called "the incumbent", requires an initial outlay of value $K_{I}$ to undertake his project. He succeeds in producing a valuable new product or process at $t=1$ with probability $\alpha$ : we can think of this as capturing the quality of the entrepreneur and his idea. A valuable innovation can be patented with probability $\beta$, which depends on the characteristics of the product. For simplicity, $\beta$ is assumed to take one of two values, $\beta_{G}$ or $\beta_{B}$, with equal probability $\left(\beta_{G}>\beta_{B}>0\right)$. If the innovation is patented, the incumbent's project yields verifiable returns $R$ at $t=2$ with probability $\gamma$, and 0 otherwise, where $R>K_{I}>0$. However, if the innovation is not patented and a potential competitor has entered the industry, the incumbent's probability of success (high 
returns) is reduced to $\gamma-\mu>0$.

For simplicity, we assume that in the absence of an innovation, the incumbent's returns are equal to zero.

\subsection{THE ENTRANT}

At $t=1$, a second entrepreneur (henceforth also called the entrant or rival) may enter the industry and invest in a competing project. The entrant's project requires an initial outlay of value $K_{E}$. It succeeds with probability $\rho$, unless the incumbent obtains a patent for his innovation: in this case the entrant's probability of success is reduced to zero. Success yields returns $Y$ while failure yields zero; $Y>K_{E}>0$.

\subsection{INVESTORS}

Entrepreneurs may seek financing from a venture capitalist, or from other investors. A venture capitalist who funds the incumbent, and interacts closely with him during the first period, is assumed to possess enough information, expertise and industry-specific knowledge to be able to evaluate the probability that a patent application by the incumbent will be successful. Other venture capitalists, who have not been involved in the development of the innovation during the first period, will not have sufficient information, and will not be able to evaluate this probability correctly. Nor will other investors, even if they have funded the incumbent at the beginning, because they will not possess the necessary industry-specific knowledge and expertise.

To focus on the implications of this informational difference, we abstract from other differences between venture capitalists and other investors, and assume that they are all competitive.

\subsection{INFORMATION}

Our key informational assumption, as mentioned above, is that the realization of $\beta$ at $t=1$ is only observed by the venture capitalist that has funded the incumbent (if external finance is raised from a venture capitalist). The idea is that firm "insiders" possess an informational advantage concerning the innovation, which is not fully disclosed in the patent application; moreover, venture capitalists have greater expertise and industry-specific knowledge enabling them to assess the likelihood that an innovation will be granted a patent. 
This assumption is consistent with the findings by Haeussler, Harhoff and Müller (2009), discussed in section 2, showing that venture capitalists are highly effective in identifying high-quality patent applications.

\subsection{ASSUMPTIONS}

We make the following assumptions throughout the analysis:

(A1) $\frac{1}{2}\left[\left(1-\beta_{G}\right)+\left(1-\beta_{B}\right)\right] \rho Y<K_{E}$

This implies that in the absence of any information concerning the realization of $\beta$, the expected return from funding the entrant is negative once the incumbent applies for patent protection for his innovation.

(A2) $\left(1-\beta_{B}\right) \rho Y>K_{E}>\left(1-\beta_{G}\right) \rho Y$

The entrant's expected profits are strictly positive when the probability of a patent being granted to the incumbent is low, and strictly negative when the probability of a patent being granted to the incumbent is high.

\subsection{TIME LINE}

$$
\begin{array}{lcc}
t=0 & t=1 & t=2 \\
\overline{\text { Incumbent }}------- & \text { Innovation? } & ------\overline{-}-\overline{-}-\overline{-}---- \\
\text { seeks funding. } & \text { VC observes } \beta . & \text { realized. } \\
\text { If funded, invests. } & \text { Patent application? } & \text { Entry? } \\
& \text { Patent granted or not. }
\end{array}
$$

\section{EXTERNAL FINANCE RAISED FROM INVESTORS}

We begin by examining the case where the incumbent obtains external finance to undertake his project from investors who will not observe the realization of $\beta$ at the intermediate stage $(t=1)$. These may be "arm's length" investors, who do not interact closely with the entrepreneur while he tries to develop his innovative idea into a valuable new product or process. They may also be investors who do interact repeatedly with the entrepreneur, and are involved in a number of strategic decisions in the course of this relationship, but do not have the expertise and industry-specific knowledge required to accurately assess the probability that the new product or process will be granted a patent. 
In this case there is essentially symmetric information about $\beta$ between the "insider" investors and other, outside investors. In particular, none of them observes the realization of $\beta$ at the intermediate stage.

By assumption (A1), nobody will be willing to fund the entrant once the incumbent has applied for a patent. Outside investors will be willing to fund the entrant, on the other hand, if the incumbent does not apply for a patent, since $\rho Y>\left(1-\beta_{B}\right) \rho Y>K_{E}$. The entrepreneur will therefore apply for a patent when he develops a new product or process, and this will deter entry. Ex ante, the incumbent's expected return from his project is given simply by:

$$
U_{N}=\alpha \gamma R-K_{I}
$$

\section{EXTERNAL FINANCE RAISED FROM A VENTURE CAPITALIST}

In this section, we assume that the incumbent obtains the required initial funding for his project from a venture capitalist, who will interact closely with the incumbent during the first period, and have sufficient information, as well as the necessary expertise and industry-specific knowledge, to assess the probability that the incumbent's patent application will be successful.

At the intermediate stage $(t=1)$, we now have asymmetric information between the venture capitalist who has funded the incumbent, and other investors: the former observes the realization of $\beta$, while the latter do not.

From assumption (A1), as before, we know that in the absence of any information concerning the realization of $\beta$, investors will not be willing to fund the entrant once the incumbent has applied for a patent. Moreover, the incumbent is better off applying for a patent when he develops a new product, because in the absence of a patent application investors will always finance the entrant.

The difference with the previous section is that the venture capitalist who has funded the incumbent now observes the realization of $\beta$. When $\beta$ is low $\left(\beta_{B}\right)$, the venture capitalist may be willing to fund the entrant. We assume for simplicity that in this case the venture capitalist would extract all the surplus from the transaction, since the entrant could not obtain funding from another source. Denote the surplus by $S \equiv\left(1-\beta_{B}\right) \rho Y-K_{E}$. To ensure that the venture capitalist funds the entrant only when this is efficient, the venture capitalist can be given a claim to the final returns from the incumbent's project (i.e. $R$ ), in return for a transfer $T$ to the incumbent. This means that the venture capitalist 
fully internalizes the costs for the incumbent's project when he decides whether to fund the entrant. The venture capitalist will then finance the entrant if, and only if, the following condition holds:

$(C 1) S>\left(1-\beta_{B}\right) \mu R$.

Ex ante, the incumbent's expected return from his project is now given by:

$$
U_{V C}=\alpha \max \left[\gamma R, \gamma R+S-\left(1-\beta_{B}\right) \mu R\right]-K_{I}
$$

which will be higher than the expected return when financing is raised from other investors if condition $(C 1)$ holds.

We can define the threshold value $\alpha_{V C}^{*}$ as the value of $\alpha$ for which $U_{V C}=0$, and the threshold value $\alpha_{N}^{*}$ as the value of $\alpha$ for which $U_{N}=0$. These are the threshold values for $\alpha$ below which entrepreneurs will not be able to obtain funding for their projects from venture capitalists and from other investors, respectively. Clearly if condition $(C 1)$ holds, $\alpha_{V C}^{*}<\alpha_{N}^{*}$; otherwise, $\alpha_{V C}^{*}=\alpha_{N}^{*}$.

\section{THEORY AND EVIDENCE}

In spite of being highly simplified and stylized, the model analyzed above already yields some insights ${ }^{9}$.

As we have just seen, venture capitalists, after funding an entrepreneur with an innovative idea, may be able to extract surplus from potential entrants at a subsequent stage, exploiting the informational advantage gained through close interaction with the first entrepreneur. Ex ante, this can make it possible to obtain funding for innovative projects that would not be financed by other investors: in the model, this will be the case if $U_{V C}>0>U_{N}$.

There are then two effects on innovation: a direct effect on the number of innovative projects that are undertaken, and an indirect effect on the average quality of funded projects. The first effect is obviously positive; it is analogous to the effect of monitoring by venture capitalists (as in, for example, Holmström and Tirole (1997)), in the sense that it relaxes firms' financing constraint, albeit for a quite different reason.

The second effect can be seen by noting that $\alpha_{V C}^{*}<\alpha_{N}^{*}$. Thus ceteris paribus the average quality of projects, as measured by the probability of innovation $\alpha$, will be lower among venture-backed entrepreneurs than among those funded by other investors. Obviously this effect is due to the assumption that $\alpha$ is perfectly

\footnotetext{
${ }^{9}$ For a richer model and analysis, see Dessi and Yin (2010).
} 
observed by venture capitalists and other investors alike. Nevertheless, it illustrates in a simple way the point made at the end of section 2 , that the endogeneity of venture capital funding can be due to a variety of reasons (not just the screening hypothesis), and the nature of the resulting bias in empirical estimates cannot be predicted with confidence.

The model analyzed in the previous section is very simple in many respects, and further insights can be gained by relaxing some of the assumptions. For example, the probability of developing a valuable new product is assumed to be exogenous: it does not depend on the entrepreneur's effort. One consequence of this is that the projects that are funded when $U_{V C}>0>U_{N}$ would not be worth funding without the possibility of extracting surplus from potential entrants. However, once the model is extended to allow for the need to induce the entrepreneur to provide effort, it will typically be the case that the entrepreneur will earn some rents, reducing the returns that can be earned by outside investors, so that some projects that would be worth funding cannot obtain outside financing. In this case, the venture capitalist's ability to extract surplus (informational rents) from potential entrants can make it possible to undertake projects that would be profitable even on a stand-alone basis, but would be denied funding (Dessí (2009)).

Moreover, and for the same reason, venture funding may make it possible to give more high-powered incentives to the entrepreneur (since the expected surplus from new entrants relaxes the venture capitalist's participation constraint), increasing his effort (Dessí (2009)), and hence the probability of developing a valuable new product or process.

\section{CONCLUSIONS}

The existing empirical literature has shown considerable ingenuity in addressing the challenges of establishing and quantifying a causal relationship between venture capital and innovation. There remains plenty of scope, on the other hand, for further work shedding light on the precise mechanisms through which venture capital fosters innovation. In this chapter, we have argued, using a simple model to illustrate our point, that a close interaction between theoretical and empirical analysis offers a promising avenue for future research. For example, our model suggests that the link between venture funding and innovative performance at the level of the individual firm may depend on the potential for surplus extraction from other firms, and hence on industry characteristics and structure. It would 
be interesting to explore this empirically in future work.

The theoretical analysis could be extended in a number of directions: for example, allowing for exit decisions. The allocation of control rights has been shown to be important for exit decisions (Cumming (2008), Dessí (2005), Hellmann (2006)), and the design of optimal contracts for innovative entrepreneurs in the presence of exit decisions as well as potential entry by competing firms deserves further study. Empirically, much work also remains to be done to investigate the relationship between the form of contracts used by venture capitalists (e.g. control rights, staging, syndication) and innovation.

Finally, it is worth emphasizing the limitations of the simple analysis presented in this chapter. For example, we have focused primarily on the role of private, limited partnership venture capital funds, with no strategic or public interest in innovation per se. The role of corporate and government venture capital has been studied elsewhere (see Gompers and Lerner (2004)), and represents an important part of the link between venture capital and innovation.

\section{REFERENCES}

Admati, Anat R. and Paul Pfleiderer. 1994. Robust financial contracting and the role of venture capitalists. Journal of Finance 49:371-402.

N. Berger, Allen and Gregory F. Udell. 1998. The economics of small business finance: The roles of private equity and debt markets in the financial growth cycle. Journal of Banking \& Finance 22(6-8):613-673.

Bottazzi, Laura, Marco Da Rin, and Thomas Hellmann. 2005. What Role of Legal Systems in Financial Intermediation? Theory and Evidence. mimeo, Università Bocconi.

Brander, James A., Raphael Amit and Werner Antweiler. 2002. VentureCapital syndication: improved venture selection vs. the value-added hypothesis. Journal of Economics and Management Strategy 11:423-452.

Casamatta, Catherine and Carole Haritchabalet. 2006. Competition between informed venture capitalists for the financing of entrepreneurs. Working Paper. University of Toulouse.

Casamatta, Catherine and Carole Haritchabalet. 2007. Experience, screening and Syndication in Venture Capital Investments. Journal of Financial Intermediation 16:368-398.

Caselli, Stefano, Stefano Gatti and Francesco Perrini. 2010. Are venture capitalists a catalyst for innovation, or do they simply exploit it? European Financial 
Management 15(1):92-111.

Cestone, Giacina. 2002. Venture Capital Meets Contract Theory : Risky Claims or Formal Control? CEPR Discussion Paper No. 3462. Available at SSRN: http://ssrn.com/abstract $=328160$.

Cestone, Giacina and Lucy White. 2003. Anti-competitive financial contracting: the design of financial claims. Journal of Finance 58:2109-2142.

Colombo, Massimo G., Luca Grilli, and Evila Piva. 2006. In search of complementary assets: the determinants of alliance formation of high-tech start-ups. Research Policy 35(8):1166-99.

Cosh, Andy, Douglas Cumming and Alan Hughes. 2009. Outside Enterpreneurial Capital. Economic Journal 119(540):1494-1533.

Cumming, Douglas. 2008. Contracts and Exits in Venture Capital Finance. Review of Financial Studies 21(5):1947-1982.

Cumming, Douglas, Grant Fleming and Suchard, Jo-Ann. 2005. Venture capitalist value-added activities, fundraising and drawdowns. Journal of Banking and Finance 29:295-331.

Da Rin, Macor and María Fabiana Penas. 2007. The effect of venture capital on innovation strategies. NBER Working Paper.

Dessí, Roberta. 2005. Start-up finance, monitoring, and collusion. Rand Journal of Economics 36(2):255-274.

Dessí, Roberta. 2009. Contractual execution, strategic incompleteness and venture capital. CEPR Discussion Paper.

Dessí, Roberta. 2010. Venture capitalists, monitoring and advising. in D. Cumming (ed.) Companion to Venture Capital, Wiley.

Dessí, Roberta and Nina Yin. 2010. Venture capitalists, innovation quality and rent extraction. mimeo, Toulouse School of Economics.

Engel, Dirk and Max Keilbach. 2007. Firm level implications of early stage venture capital investment - an empirical investigation. ZEW Discussion Paper.

Gans, Joshua S., David H. Hsu and Scott Stern. 2002. When does startup innovation spur the gale of creative destruction. Rand Journal of Economics 33(4):571-86.

Garmaise, Mark J.. 2006. Informed investors and the financing of entrepreneurial projects. Working Paper, Chicago GSB.

Gompers, Paul and Josh Lerner. 2004. The Venture Capital Cycle, The MIT Press.

Gompers, Paul and Josh Lerner. 2000. Money chasing deals? The impact of fund inflows on private equity valuation. Journal of Financial Economics 55:281- 
325 .

Gorman, Michael and William A. Sahlman. 1989. What do venture capitalists do? Journal of Business Venturing 4:231-248.

Haeussler, Carolin, Dietmar Harhoff and Elisabeth Müller. 2009. To be financed or not - the role of patents for venture capital financing. CEPR Discussion paper.

Hellmann, Thomas. 1998. The Allocation of Control Rights in Venture Capital Contracts. Rand Journal of Economics 29:57-76.

Hellmann, Thomas. 2006. IPOs, acquisitions, and the use of convertible securities in venture capital. Journal of Financial Economics 81(3):649-679.

Hellmann, Thomas and Manju Puri. 2000. The interaction between product market and financing strategy: the role of venture capital. Review of Financial Studies 13: 959-984.

Hellmann, Thomas and Manju Puri. 2002. Venture Capital and the Professionalization of Start-up Firms: Empirical Evidence. Journal of Finance. 57:169197.

Holmstrom, Bengt and Jean Tirole. 1997. Financial Intermediation, Loanable Funds, and the Real Sector. Quarterly Journal of Economics CXII:663-691.

Hsu, David H.. 2006. Venture capitalists and cooperative start-up commercialization strategy. Management Science 52:204-219.

Jeng, Leslie A. and Phillippe C. Wells. 2000. The determinants of venture capital funding: evidence across countries. Journal of Corporate Finance. 6:241289.

Kaplan, Steven N. and Per Strömberg. 2003. Financial contracting theory meets the real world: an empirical analysis of venture capital contracts. Review of Economic Studies 70(243):281-315.

Kaplan, Steven N. and Per Strömberg. 2004. Characteristics, contracts, and actions: evidence from venture capitalist analyses. Journal of Finance 59:21772210 .

Kortum, Samuel S. and Josh. Lerner. 2000. Assessing the contribution of venture capital to innovation. Rand Journal of Economics 31(4):674-692.

Lerner, Josh. 1994. The syndication of venture capital investments. Financial Management 23:16-27.

Lerner, Josh. 1995. Venture Capitalists and the Oversight of Private Firms. Journal of Finance 50:301-318.

Lerner, Josh. 2002. Boom and bust in the venture capital industry and the impact on innovation. Federal Reserve Bank of Atlanta Economic Review 25-39. 
Lerner, Josh and Antoinette Schoar. 2005. Does Legal Enforcement Affect Financial Transactions? The Contractual Channel in Private Equity. Quarterly Journal of Economics 120:223-246.

Peneder, Michael. 2010. The impact of venture capital on innovation behaviour and firm growth. Venture Capital 12(2):83-107.

Repullo, Rafael and Javier Suarez. 2000. Entrepreneurial Moral Hazard and Bank Monitoring: A Model of the Credit Channel. European Economic Review 44:1931-1950.

Repullo, Rafael and Javier Suarez. 2004. Venture Capital Finance: A Security Design Approach. Review of Finance 8:75-108.

Riyanto, Yohanes E. and Armin Schwienbacher. 2006. The strategic use of corporate venture financing for securing demand. Journal of Banking and Finance 30:2809-2833.

Sahlman, William A.. 1990. The structure and governance of venture-capital organizations. Journal of Financial Economics 27:473-521.

Schmidt, Klaus M.. 2003. Convertible securities and venture capital finance. Journal of Finance 58(3):1139-1166.

Ueda, Masako. 2004. Banks versus venture capital: project evaluation, screening, and expropriation. Journal of Finance, 59(2):601-621.

Ueda, Masako and Masayuki Hirukawa. 2008. Venture capital and industrial "innovation". CEPR Working Paper 7089. 


\section{Table 1}

\begin{tabular}{|c|c|c|c|c|}
\hline Author & Sample Description & Data Source & Method of Analysis & Summary of Findings \\
\hline $\begin{array}{l}\text { Kortum and Lerner } \\
\text { (2000) }\end{array}$ & $\begin{array}{l}20 \text { U.S. manufacturing } \\
\text { industries between } 1965 \\
\text { and } 1992\end{array}$ & $\begin{array}{l}\text { Industry patent counts are based on the } \\
\text { International Patent Classification } \\
\text { assigned to each patent issued by } \\
\text { USPTO; Venture funding collected by } \\
\text { Venture Economics; Industrial R\&D } \\
\text { expenditures collected by USF }\end{array}$ & $\begin{array}{l}\text { IV estimation which exploits the policy } \\
\text { shift of US freeing pension to invest in } \\
\text { venture capital in } 1979 \text {; alternative } \\
\text { method is using R\&D as controls to } \\
\text { disentangle the endogeneity problem. }\end{array}$ & $\begin{array}{l}\text { The impact of venture capital on technological } \\
\text { innovation is positive and significant, which is } \\
3 \text { times as potent as the corporate R\&D and } \\
\text { accounts for } 8 \% \text { of industrial innovations in the } \\
\text { decade ending in } 1992 \text {. }\end{array}$ \\
\hline $\begin{array}{l}\text { Ueda and } \\
\text { Hirukawa (2008) }\end{array}$ & $\begin{array}{l}19 \text { U.S. manufacturing } \\
\text { industries from } 1965 \text { to } \\
2001\end{array}$ & $\begin{array}{l}\text { Venture Economics proprietary } \\
\text { database(VentureXpert), the NBER } \\
\text { productivity Database, the NBER } \\
\text { Patent database, and the NSF R\&D } \\
\text { database. }\end{array}$ & $\begin{array}{l}\text { Similar methods as in Kortum and Lerner } \\
(2000)(\mathrm{KL}) \text { adopted to re-examine the } \\
\text { results of KL in a extended period; } \\
\text { Alternatively, utilizing total factor } \\
\text { productivity (TFP) growth and labor } \\
\text { productivity growth as measures of } \\
\text { innovation. }\end{array}$ & $\begin{array}{l}\text { The regressions for patent counts confirm the } \\
\text { findings of KL with bigger coefficients. But } \\
\text { there is no significant impact of venture capital } \\
\text { on TFP growth; Although the impact of VC on } \\
\text { labor productivity growth is positive and } \\
\text { significant however, it is driven by } \\
\text { substitutions of input factors away from labor. }\end{array}$ \\
\hline $\begin{array}{l}\text { Hellman and Puri } \\
\text { (2000) }\end{array}$ & $\begin{array}{l}173 \text { start-up companies that } \\
\text { are located in California's } \\
\text { Silicon Valley, which is } \\
\text { culled from two database } \\
\text { and the Silicon Valley } \\
\text { business press }\end{array}$ & $\begin{array}{l}\text { A uniquely hand-collected dataset built } \\
\text { upon surveys, interviews and } \\
\text { commercial databases, as well as any } \\
\text { publicly available information }\end{array}$ & $\begin{array}{l}\text { Probit model to examine the likelihood of } \\
\text { a company receiving venture capital } \\
\text { financing; Cox proportional hazard model } \\
\text { to explore whether the product strategy } \\
\text { affects the time to receiving VC and } \\
\text { whether the VC financing affects the time } \\
\text { to market. }\end{array}$ & $\begin{array}{l}\text { Innovators are more likely to be financed by } \\
\text { venture capital than are imitators. And } \\
\text { innovators obtain venture capital earlier in the } \\
\text { life cycle than do imitators. Venture-based } \\
\text { companies, especially innovators are faster in } \\
\text { bringing their product to market. }\end{array}$ \\
\hline $\begin{array}{l}\text { Engel and } \\
\text { Keilbach (2007) }\end{array}$ & $\begin{array}{l}\text { All German firms starts-up } \\
\text { between } 1995 \text { and 1998, } \\
\text { including } 50754 \text { non } \\
\text { venture funded firms and } \\
274 \text { venture funded firms. }\end{array}$ & $\begin{array}{l}\text { A dataset which merged ZEW- } \\
\text { Foundation panels provided by } \\
\text { Creditreform (the largest German credit } \\
\text { rating agency) with information from } \\
\text { other sources, including DPA patent } \\
\text { application data. }\end{array}$ & $\begin{array}{l}\text { Propensity score matching procedure to } \\
\text { alleviate selection bias which arises from } \\
\text { tthe extensive pre-investment screening } \\
\text { process of VC. }\end{array}$ & $\begin{array}{l}\text { Firms with higher patent applications and } \\
\text { higher educated management have a larger } \\
\text { probability of being venture funed. And } \\
\text { venture-based firms display a higher growth } \\
\text { rate than the comparable non venture-funded } \\
\text { firms, however, their innovative performance } \\
\text { doesn't show significant difference. }\end{array}$ \\
\hline
\end{tabular}




\section{Table 1(Continued)}

\begin{tabular}{llll}
\hline Author & Sample Description & Data Source & Method of Analysis \\
\hline $\begin{array}{l}\text { Caselli, Gatti and } \\
\text { Perrini (2008) }\end{array}$ & $\begin{array}{l}\text { 153 Italian IPOs firms } \\
\text { between1995 and 2004, } \\
\text { including } 37 \text { venture- } \\
\text { funded firms and } 116 \text { non } \\
\text { venture-funded firms. }\end{array}$ & $\begin{array}{l}\text { A self-collected dataset based on the } \\
\text { information provided by Italian } \\
\text { Association of VC and PE operators, } \\
\text { VC-funded companies and the Italian } \\
\text { Trademark and Patents Office. }\end{array}$ & $\begin{array}{l}\text { Similar methods as in Engel and Keilbach } \\
(2007) .\end{array}$ \\
Peneder (2010) & $\begin{array}{l}\text { 250,000 Austrian } \\
\text { companies including 166 } \\
\text { venture funded companies. }\end{array}$ & $\begin{array}{l}\text { Database collected by Austrian Private A two-stage propensity score matching. } \\
\text { Organization (AVCO) combined with } \\
\text { firm database provided by the leading } \\
\text { Austrian credit rating agency and a } \\
\text { comprehensive entreprise survey. }\end{array}$ & \\
& &
\end{tabular}

Haeussler, Harhoff 190 German and British and Muller (2009) biotechnology companies founded after 1989; 87 them are VC-financed and 103 of them are non VC

Da Rin and Penas (2007)

$$
\text { financed. }
$$

Questionare surveys; face-to-face

Cox proportional hazard model to interviews with companies; and official investigate how patent related variables patent reports from European Patent Office(EPO).

7808 Netherland portfolio CIS survey data covering 1998-2004 VC-financed; 7717 of them developed by OECD and EPO. are non VC-financed.
Summary of Findings

The entry of venture capital into the company does not promote continued innovation, but mainly develops the sales.

VC-backed firms are constrained to obtain financing through traditional channels. VCbacked firms are more innovative which is prove to be a pure selection effects. And they grow faster in term of turnover and employment which encompass both causal effects and selection effects.

Signals generated in patenting process increase VC financing and attract VC faster. Companies with higher quality of patent (measured in citation) receive VC faster, while patent indicators generated by patent examiner has weak effects on VC financing which indicates that VCs are capable of detecting high-quality patent applications at the early stage.

Probit model to examine the relationship Venture capital favors the build-up of between VC and innovation strategies; absorptive capacity and results in a more furthermore, propensity score method to permanent in-house R\&D efforts. While the distinguish treatment effect from selection public funding relaxes the financial constraints, effect.

capacity. 